\title{
Gulzige organisaties en de verdeling van betaalde en onbetaalde arbeid binnen huishoudens
}

\author{
Babette Pouwels, Jacques Siegers, Joop Schippers, \\ Rafael Wittek \& Philip Wotschack ${ }^{1}$
}

\section{Summary}

Firm's time greediness and the division of labour in the household

Although the body of literature documenting the division of labour between partners is large and continuously expanding, little is known about how demands and expectations from the workplace affect the division of labour between partners and how spouses use strategies to manage, or 'govern', the conflicting demands of work and family. Using data on 242 Dutch female employees, their partners and their employers, the results from multilevel analysis show that the more demanding the woman's job is, the larger her share in paid work and the smaller her share in household work are. These effects are moderated by both workplace governance practices and household governance practices. These effects are moderated by both workplace governance practices and household governance practices.

\section{Inleiding}

Steeds minder huishoudens hanteren een strikte taakverdeling, waarbij de man exclusief door middel van betaald werk buitenshuis het gezinsinkomen verdient om vrouw en kinderen van te onderhouden en de vrouw zich voltijd en uitsluitend bezighoudt met het huishouden en de zorg voor kinderen. Een hoger opleidingsniveau en meer verdiencapaciteit maakt het voor vrouwen aantrekkelijker de arbeidsmarkt te betreden en naast een loopbaan als moeder ook een professionele loopbaan na te streven. Onder invloed van emancipatoire krachten in de samenleving groeit het aantal huishoudens waarin beide partners betaald werk en zorgtaken combineren (Blossfeld \& Drobnič, 2001; Bovenberg, 2005; Schippers, 2001). Met de groei van het aantal taakcombineerders wordt 
ook de verdeling van beide categorieën taken binnen huishoudens een punt van discussie (Jacobs \& Gerson, 2001). Wie brengt en wie haalt de kinderen? Wie doet de boodschappen, wie kookt en wie maakt de badkamer schoon? In moderne huishoudens moeten partners deze vragen rond de taakverdeling van het onbetaalde werk beantwoorden tegen de achtergrond van de eisen die het werk en de organisatie van beide partners stellen (Gill, 1998; Hochschild, 1997; Perlow, 1998). Zowel de organisatie waar elk der partners werkt als het gezin kunnen worden gekarakteriseerd als gulzige instituties die tegelijkertijd tijd en energie vergen van de leden die ertoe behoren (Coser, 1974; Tausig \& Fenwick, 2001). Partners staan dus zowel individueel als gezamenlijk voortdurend voor de noodzaak af te wegen welke claims op hun tijd wel en niet te honoreren en hoe hun activiteiten onderling af te stemmen (Greenstein, 1996; Kluwer, Heesink, \& Van de Vliert, 1997). Aldus is de taakverdeling tussen partners niet langer een vast gegeven zoals 'vroeger', in de tijd van het kostwinnersmodel, maar onderwerp van voortdurend overleg of onderhandeling tussen de partners (Greenstein, 1996; Kluwer, 1998).

Tal van studies zijn eerder gewijd aan de taakverdeling tussen partners. Theoretische verklaringsmodellen voor die taakverdeling benadrukken veelal de rol van individuele en gemeenschappelijke hulpbronnen, opvattingen over gendergelijkheid en de verantwoordelijkheid voor zorgtaken en de eisen die vanuit het gezin worden gesteld (Blossfeld \& Drobnič, 2001; Coltrane, 2000; Lewin-Epstein, Stier \& Braun, 2006; Shelton \& John, 1996; Van der Lippe \& Siegers, 1994). In moderne huishoudens komt daar echter nog een factor bij: de eisen en verwachtingen waarmee elk der partners vanaf het werkfront worden geconfronteerd. Tot dusver heeft de literatuur weinig aandacht besteed aan het effect dat deze eisen en verwachtingen hebben op de taakverdeling binnen huishoudens en aan de strategieën die partners gebruiken om de conflicterende claims vanuit het gezin en de organisaties met elkaar te verzoenen.

De centrale vraag in dit onderzoek is in hoeverre de eisen die vanuit het werk aan vrouwen worden gesteld, van invloed zijn op de taakverdeling thuis. Op de tweede plaats onderzoeken we in hoeverre verschillende 'governance'-regimes op het werk en binnen het huishouden deze relatie beïnvloeden. Voor de empirische analyses gebruiken we gegevens van vrouwelijke werknemers, hun werkgevers en hun partners uit het Time Competition Survey 2003 (Van der Lippe \& Glebbeek, 2003). 


\section{Theorie}

\section{I De verdeling van betaalde en onbetaalde arbeid tussen partners}

Twee theoretische perspectieven overheersen in het wetenschappelijke debat over de vraag waarom vrouwen binnen huishoudens nog steeds het grootste deel van het huishouden en de zorg voor kinderen op zich nemen, terwijl mannen verantwoordelijk zijn voor het leeuwendeel van de betaalde arbeid: (1) theorieën over relatieve hulpbronnen en (2) gendertheorieën (Bittman e.a., 2003; Evertsson \& Nermo, 2004; LewinEpstein, Stier \& Braun, 2006; Van der Lippe \& Siegers, 1994).

Veelgebruikte theorieën over relatieve hulpbronnen zijn de new home economics (Becker, 1981, 1991), resource bargaining-benaderingen (Blood \& Wolfe, 1960) en het model van economische afhankelijkheid (Brines, 1994). Deze theorieën hebben met elkaar gemeen dat ze de nadruk leggen op ruilrelaties en de individuele keuze van mensen. Verder veronderstellen ze dat mensen liever geen tijd willen besteden aan onbetaalde arbeid en dat de verdeling van betaalde arbeid één op één samenhangt met de verdeling van onbetaalde arbeid. Ze zijn bovendien genderneutraal geformuleerd (Coltrane, 2000: 1214). Voor een gedetailleerde beschrijving van deze theorieën over relatieve hulpbronnen verwijzen we naar Bianchi e.a. (2002), Coltrane (2000), Shelton \& John (1996) en Van der Lippe \& Siegers (1994).

Al deze benaderingen leiden uiteindelijk tot de centrale hypothese dat de partner met het hoogste uurloon de meeste tijd zal besteden aan betaalde arbeid, terwijl de ander de meeste tijd zal besteden aan onbetaalde arbeid. Een hypothese die keer op keer bevestigd wordt in empirisch onderzoek (voor voorbeelden zie Brines (1994), Greenstein (2000), Presser (1994) en Van der Lippe \& Siegers (1994)). Op basis hiervan verwachten we dan ook dat vrouwen binnen het huishouden een groter aandeel hebben in betaalde arbeid naarmate hun relatieve uurloon hoger is (H1a) en - als gevolg daarvan - een kleiner aandeel in onbetaalde arbeid (H1b).

Theorieën over relatieve hulpbronnen gaan ervan uit dat de aanwezigheid van kinderen de taakspecialisatie in het huishouden versterkt. Kinderen kosten tijd (vooral als ze jong zijn) en geld (vooral als ze ouder worden). Omdat vrouwen in het algemeen een lagere verdiencapaciteit hebben dan hun mannelijk partners, is de verwachting dat zij vaker zullen opdraaien voor de tijdkosten. Dit betekent dat zij meer tijd besteden aan huishouden en kinderzorg, terwijl hun partners de financiële kosten op zich zullen nemen. Die partners zullen meer uren werken op de arbeidsmarkt. Het negatieve effect van kinderen op de tijd die de vrouw aan onbetaalde arbeid besteedt, zal groter zijn wanneer de kinderen jong zijn. Het positieve effect van kinderen op de tijd die haar partner 
aan betaalde arbeid besteedt, zal daarentegen sterker zijn wanneer de kinderen ouder worden. Op basis van het bovenstaande verwachten we dan ook dat de aanwezigheid van kinderen in het huishouden het aandeel van de vrouw in betaalde arbeid verkleint (H2a) en haar aandeel in onbetaalde arbeid vergroot (H2b). Beide effecten zullen sterker zijn naarmate de kinderen jonger zijn (H2c en H2d).

Gendertheorieën benadrukken het belang van gender als centraal ordeningsprincipe in de samenleving. Ze wijzen erop dat gender van invloed is op de taakverdeling binnen het huishouden, los van een eventuele ongelijke verdeling van hulpbronnen. Mensen met traditionele genderopvattingen zullen naar verwachting ook traditionele tijdsbestedingspatronen hebben en de taken thuis traditioneel verdelen (zie ook Bianchi e.a., 2000; Bittman e.a., 2003; Greenstein, 1996). Ze reproduceren op deze manier genderverhoudingen, doordat ze de bestaande normen bestendigen. Voor vrouwen betekent dit dat ze meer tijd zullen besteden aan onbetaalde arbeid. Mannen zullen juist meer tijd besteden aan betaalde arbeid. Mensen met egalitaire genderopvattingen daarentegen zullen minder de behoefte voelen om bestaande genderrollen te reproduceren door middel van hun tijdsbesteding of taakverdeling. Ze zullen hun tijd aan betaalde en onbetaalde arbeid dan ook gelijker verdelen. Naarmate de genderopvattingen van partners meer egalitair zijn, zal het aandeel van de vrouw in betaalde arbeid naar verwachting dan ook groter zijn (H3a) en haar aandeel in onbetaalde arbeid kleiner (H3b).

\subsection{Gulzige organisaties}

In moderne huishoudens wordt de taakverdeling al lang niet meer alleen bepaald door de tijd en energie die het gezin van de gezinsleden vraagt en de aanwezige hulpbronnen of de heersende opvattingen over mannelijkheid en vrouwelijkheid. Ook banen en werkgevers eisen tijd en energie, en vormen aldus restricties. Werkgevers kunnen 'gulzig' zijn en veel tijd en energie vragen van hun werknemers. Op huishoudniveau zou dat gevolgen kunnen hebben voor de verdeling van werk en zorgtaken tussen de werknemer en haar of zijn partner.

Hoewel er steeds meer studies verschijnen over de invloed van betaald werk op het gezinsleven en omgekeerd (zie bijvoorbeeld Cunningham, 2007; Glass \& Camarigg, 1992; Noonan, Estes \& Glass, 2007; Tausig \& Fenwick, 2001), is er nog weinig onderzocht in welke mate de eisen en verwachtingen die vanuit het werk en de arbeidsorganisatie aan werknemers worden gesteld effect hebben op de tijdsallocatie van werknemers. Er zijn een paar uitzonderingen. Zo heeft Schor (1993) geanalyseerd hoe Amerikaanse arbeidsorganisaties hun werknemers 'dwingen' om meer tijd te besteden aan hun werk. Ook onderzoek van Maume en Bellas 
(2001) en Clarberg en Moen (2001) in de VS laat zien dat hoge eisen van zowel organisaties als leidinggevenden de werkweek van werknemers aanzienlijk kunnen verlengen. Daarnaast blijkt een 'overwerkcultuur' met een hoge werkdruk (Rutherford, 2001) en een competitieve werksfeer (Perlow, 1998) een positief effect te hebben op het aantal uren dat werknemers per week werken. In welke mate de eisen die het werk en de organisatie aan hun werknemers stellen effect hebben op de taakverdeling tussen werknemers en hun partners thuis is, voor zover we weten, niet eerder in Nederland onderzocht.

Werk kan op verschillende manieren veeleisend zijn. Een baan kan fysieke eisen stellen aan werknemers (zwaar tillen, diep bukken), psychologische eisen (hoge targets, strakke deadlines, werken in een competitieve werksfeer), of eisen stellen aan de werklast en uitvoering van taken (veel werk, complexe taken, onder hoge druk werken; zie ook: De Jonge, Dollard, Dormann, Le Blanc \& Houtman, 2000). Omdat we in dit onderzoek vooral geïnteresseerd zijn in de 'gulzige', tijdslurpende aspecten van het werk, concentreren we ons specifiek op de psychologische eisen en eisen die gerelateerd zijn aan de werklast en de uitvoering van taken.

Voor veel werkgevers is de ideale werknemer iemand die continu beschikbaar is voor het werk, buiten het werk weinig verplichtingen heeft en voor wie de organisatie op de eerste plaats komt (Acker, 1998; Benschop, 1996). Tijd investeren in het werk is een manier voor werknemers om dergelijk commitment aan de organisatie te tonen. Dergelijke investeringen leveren werknemers vaak extra voordelen op, zoals extra waardering en betere promotiekansen. Wie in een organisatie werkt waar een hoge inzet en betrokkenheid bij het werk belangrijk gevonden worden of wie in zijn of haar functie te maken krijgt met hoge targets en strakke deadlines, zal eerder de noodzaak voelen om meer tijd in het werk te investeren dan wie in een minder veeleisender organisatie of functie werkt. We verwachten dan ook dat vrouwen met een veeleisende baan meer tijd zullen besteden aan betaalde arbeid. Daardoor zal hun relatieve aandeel in betaalde arbeid thuis groter worden (H4a). Tegelijkertijd zullen deze vrouwen minder tijd besteden aan onbetaalde arbeid, waardoor hun aandeel in onbetaalde arbeid thuis kleiner zal worden (H4b).

\section{3 'Governance'-regimes}

In het algemeen wordt aangenomen dat een veeleisende baan negatieve gevolgen heeft voor de balans tussen werk en privé. Onze benadering gaat ervan uit dat werknemers en hun partners zich niet simpelweg voegen naar de wensen en eisen van hun werkgever(s) of hun gezin, maar dat ze strategieën en spelregels inzetten om te bepalen hoe en waaraan 
zij dagelijks hun tijd besteden. Deze strategieën en spelregels worden ook wel 'governance'-regimes genoemd. 'Governance'-regimes regelen hoe, waar, wanneer en met wie mensen hun dagelijkse werk- en zorgta-

ken uitvoeren en of zij daarin veel of weinig autonomie en zeggenschap hebben. We onderscheiden twee typen: strategieën voor huishoudbeheersing en strategieën voor werkbeheersing.

\subsection{Strategieën voor huishoudbeheersing}

Geïnspireerd door de sociologische studies van het huishouden van Gill (1998) en Perlow (1998) definiëren we strategieën voor huishoudbeheersing als beheersingsmechanismen die de tijdsallocatie binnen het huishouden reguleren (Wotschack, 2009; Wotschack, Siegers, Pouwels \& Wittek, 2007). We onderscheiden daarbij twee soorten: huishoudregels en kwaliteitsstandaarden voor de uitvoering van huishoudelijke activiteiten.

Huishoudregels zijn de afspraken die partners in een huishouden maken over de vereiste tijdbesteding van beiden aan dagelijkse huiselijke activiteiten en de onderlinge afstemming van deze activiteiten. Ze reguleren de grenzen tussen betaalde en onbetaalde arbeid. Hoe stringenter de huishoudregels, hoe sterker de tijdbestedingspatronen van partners gereguleerd worden. Huishoudregels regelen de input voor huiselijke activiteiten.

Partners kunnen tijdplanningen, roosters en regels gebruiken om hun tijdbesteding aan werk en zorg te coördineren en de diverse werkzaamheden onderling te verdelen. Als de zaken thuis strak geregeld zijn, kan het voor vrouwen gemakkelijker zijn om meer uren te werken op de arbeidsmarkt. Voor hun partners is het bovendien minder eenvoudig om zich aan activiteiten thuis te onttrekken wanneer hun verantwoordelijkheden duidelijk zijn gemarkeerd. We verwachten dan ook dat strikte huishoudregels een positief effect hebben op het aandeel van de vrouw in betaalde arbeid (H5a) en een negatief effect op haar aandeel in onbetaalde arbeid (H5b).

Maar meer nog dan een zelfstandig effect van huishoudregels op de taakverdeling tussen partners, verwachten we dat partners huishoudregels zullen inzetten om de vaak tegenstrijdige eisen te reguleren die werk en gezin aan hen stellen. In het geval van veeleisend werk, het onderwerp van deze studie, zijn er twee tegengestelde effecten mogelijk: strikte huishoudregels kunnen de tijdslurpende effecten van veeleisend werk intensiveren en ze kunnen werknemers er juist tegen beschermen.

Aan de ene kant zullen vaste afspraken over de tijdsinzet van beide partners en de tijdstippen waarop wie wat doet, werknemers in staat stellen om meer uren te werken als het werk daarom vraagt. De zorg 
voor huishouden en kinderen kan immers via de huishoudregels worden gewaarborgd. Strikte huishoudregels intensiveren op deze manier het tijdslurpende effect van veeleisend werk.

Aan de andere kant vormen huishoudregels ook een restrictie voor werknemers om (zeer) lange werkweken te maken, omdat precies is vastgelegd wanneer het gezin tijd en energie van hen vraagt. Vaste afspraken thuis ontnemen werknemers voor een deel dus de flexibiliteit om hun tijdsallocatie aan te passen op momenten dat dit op het werk gewenst is. Als een werknemer op enig moment meer uren zou willen werken dan eerder thuis is afgesproken omdat haar werkgever dat van haar vraagt, heeft zij de keuze om de huishoudregels te 'overtreden' of de bestaande regels ter discussie te stellen en met haar partner te onderhandelen over nieuwe afspraken. In het eerste geval riskeert ze een conflict en de mogelijkheid om de relatie te schaden, in het tweede geval kost het haar tijd en energie om een nieuw onderhandelingsproces te starten over de tijdbesteding en taakverdeling binnen het huishouden. De uitkomst van deze processen zijn onzeker. Behalve van de doelen en restricties van beide partners, hangt de uitkomst af van hun strategieën voor onderhandeling en conflicthantering. Werknemers in strikt gereguleerde huishoudens krijgen dus te maken met additionele restricties in termen van kosten en risico's als ze meer uren zouden willen werken.

Het netto resultaat van de intensiverende en beschermende werking van huishoudregels op de effecten van veeleisend werk kan niet worden voorspeld, en moet op empirische basis worden vastgesteld. Derhalve formuleren we twee tegengestelde hypothesen. Hypothese 6 stelt dat naarmate vrouwen thuis striktere huishoudregels hebben, het positieve effect van een veeleisende baan op hun aandeel in betaalde arbeid groter is (H6a) en dat het negatieve effect van een veeleisende baan op hun aandeel in onbetaalde arbeid groter is (H6b). Hypothese 7 veronderstelt dat naarmate vrouwen thuis striktere huishoudregels hebben, het positieve effect van een veeleisende baan op hun aandeel in betaalde arbeid kleiner is (H7a) en dat het negatieve effect van een veeleisende baan op hun aandeel in onbetaalde arbeid kleiner is (H7b).

Kwaliteitsstandaarden zijn de minimumeisen die partners stellen aan de uitvoering van diverse huishoudelijke taken, zoals koken, opruimen of schoonmaken. Ze zijn een graadmeter voor de kwaliteit van de output van huiselijke activiteiten. We verwachten daarom een negatief effect van kwaliteitsstandaarden op het aandeel van de vrouw in de betaalde arbeid (H8a) en een positief effect op haar aandeel in het onbetaalde werk (H8b). Verder verwachten we dat kwaliteitsstandaarden een restrictie vormen voor de tijdsinvesteringen die vrouwen in hun werk kunnen doen als hun baan of werkgever dat van hen eist. Dit betekent dat hoge kwaliteitseisen zowel het positieve effect van werkeisen op het aandeel 
van vrouwen in betaalde arbeid als het negatieve effect op hun aandeel in onbetaalde arbeid afzwakken (H9a en H9b).

\subsubsection{Strategieën voor werkbeheersing}

Strategieën voor werkbeheersing verwijzen naar de beheersingsmechanismen die werknemers hebben om de organisatie en uitvoering van hun werk te reguleren. Het zijn de arrangementen die werknemers zeggenschap geven om zelf te bepalen waar, wanneer en hoe ze hun werk willen doen. Flexibele begin- en eindtijden, thuiswerken of de professionele autonomie om zelf de werkinhoud of -volgorde te bepalen zijn veelvoorkomende strategieën. Verschillende studies laten zien hoe zulke strategieën de combinatie van betaalde en onbetaalde arbeid eenvoudiger kunnen maken (Glass \& Camarigg, 1992; Tausig \& Fenwick, 2001). Thuiswerken biedt bijvoorbeeld ruimte om tijdens een werkdag wat kleine huishoudelijke taken te doen, zoals de vaatwasser uitruimen of de was ophangen, maar ook om 's avonds of in de weekeinden nog wat te werken om klussen af te maken. Flexibele begin- en eindtijden geven werknemers weer de mogelijkheid bepaalde zorgactiviteiten in hun werkweek in te passen, zoals het brengen of ophalen van schoolgaande kinderen. Op deze manier zijn werknemers in staat om (meer) tijd te besteden aan hun werk, zonder dat het ten koste gaat van hun huiselijke activiteiten. Andersom geven flexibele werkarrangementen werknemers de mogelijkheid om (meer) tijd te besteden aan huishoudelijke taken en zorg voor kinderen, zonder dat het ten koste gaat van hun werk. Autonomie en flexibiliteit lijken bovendien niet alleen strategieën voor werknemers om betaalde en onbetaalde arbeid beter te combineren, maar ook een middel om het werk thuis eerlijker tussen de partners te verdelen (zie ook Coltrane, 2000; Noonan, Estes \& Glass, 2007). Op basis van het bovenstaande verwachten we dan ook een hoge mate van werkbeheersing, dat wil zeggen een hoge mate van autonomie en flexibiliteit op het werk, voor vrouwen een positief effect heeft op hun aandeel in betaalde arbeid (H10a) en een negatief effect op hun aandeel in onbetaalde arbeid (H10b).

Evenals strategieën voor huishoudbeheersing, kunnen werknemers ook strategieën voor werkbeheersing inzetten om de tegenstrijdige eisen van werk en gezin te reguleren. Professionele autonomie en flexibele werkarrangementen bieden hun de mogelijkheid om snel te schakelen tussen werk en gezin, zodat ze gemakkelijker tegemoet kunnen komen aan (onverwachte) eisen vanuit beide domeinen. Anderzijds blijkt uit onderzoek dat professionele autonomie en flexibele werkarrangementen gemakkelijk kunnen leiden tot overwerk en het maken van lange werkweken (Van Echtelt, 2007). Autonomie en flexibiliteit versterken op deze manier de tijdslurpende effecten van veeleisende werkgevers. 
We verwachten dan ook dat het positieve effect van een veeleisende baan van vrouwen op hun relatieve aandeel in betaalde arbeid groter is naarmate ze in hun werk over meer autonomie en flexibiliteit beschikken (H11a). Aan de andere kant bieden professionele autonomie en flexibele werkarrangementen vrouwen de mogelijkheid om tegemoet te komen aan de hoge eisen van een werkgever, zonder dat dit gevolgen hoeft te hebben voor hun tijdsbesteding aan huishoudelijke en zorgtaken. We verwachten daarom dat ze het negatieve effect van veeleisend werk van vrouwen op hun aandeel in onbetaalde arbeid afzwakken (H11b).

\section{Data en methode}

\section{I Data}

De data zijn afkomstig van het Time Competition Survey 2003, een survey over de oorzaken van de tijdsdruk die werknemers ervaren bij het combineren van arbeid en zorg, en de oplossingen die organisaties en werknemers daarvoor vinden (Van der Lippe \& Glebbeek, 2003). In het survey werden zowel organisaties als huishoudens ondervraagd. De data zijn verzameld door middel van een getrapte steekproef onder werknemers van Nederlandse arbeidsorganisaties. In een eerste fase werden dertig organisaties uit de private en publieke sector geselecteerd die bereid waren om deel te nemen aan het onderzoek. Grotere, dienstverlenende en kennisintensieve organisaties zijn hierbij oververtegenwoordigd. In een tweede fase werden binnen elke organisatie verschillende functiegroepen geselecteerd. Een functiegroep bestaat uit werknemers die vergelijkbare taken verrichten en overeenkomstige arbeidsvoorwaarden kennen. Ook beschikken de werknemers over eenzelfde mate van flexibiliteit en autonomie bij het uitvoeren van hun functie en hebben zij dezelfde arbeidstijden en -locaties. Vervolgens werden werknemers uit deze functiegroepen telefonisch benaderd met de vraag of zij wilden deelnemen aan het onderzoek. Van werknemers met een partner werd ook de partner gevraagd om mee te doen.

In totaal werden gegevens verkregen van 1114 werknemers en hun eventuele partners, uit 89 functiegroepen binnen 30 organisaties. Van alle werknemers die aanvankelijk binnen de 30 organisaties werden benaderd, waren er 1543 bereid om mee te doen (respons van 39 procent). In een latere fase vielen 439 werknemers af, omdat hun partner medewerking weigerde. De totale respons komt daarmee op 28 procent. Voor het onderhavige onderzoek hebben we alle vrouwelijke werknemers geselecteerd die gehuwd of ongehuwd samenwonen met een mannelijke, werkende partner. Alleen huishoudens waar beide partners tus- 
sen de 18 en 65 jaar zijn, werden in de selectie opgenomen. Huishoudens waarvan een van de partners onvrijwillig werkloos is, voltijds studerend, gepensioneerd of zelfstandige, zijn buiten de analyse gelaten. Dit resulteert in een selectie van 242 vrouwelijke werknemers en 242 mannelijke partners van wie alle relevante informatie beschikbaar is. De vrouwelijke werknemers komen uit 68 functiegroepen in 26 organisaties. Alle huishoudens zijn tweeverdieners; 63 procent heeft thuiswonende kinderen.

\subsection{Operationalisering}

\subsection{Afhankelijke variabelen}

De arbeidsverdeling tussen partners hebben we in dit onderzoek geoperationaliseerd als het relatieve aandeel van de vrouw in betaalde arbeid en het relatieve aandeel van de vrouw in onbetaalde arbeid. Het relatieve aandeel van de vrouw in betaalde arbeid (onbetaalde arbeid) is gemeten door het aantal uren dat de vrouwelijke werknemer per week besteedt aan betaalde arbeid (onbetaalde arbeid) te delen door het totale aantal uren dat zij en haar man samen per week besteden aan betaalde arbeid (onbetaalde arbeid). De uitkomst wordt met 100 vermenigvuldigd, zodat het relatieve aandeel uitgedrukt wordt in percentages. De uren betaalde arbeid omvatten ook overwerk en uren in een eventuele tweede baan. Reistijd valt hier echter buiten. De uren onbetaalde arbeid omvatten de tijd besteed aan negen huishoudelijke- en zorgtaken: boodschappen doen, koken, schoonmaken, opruimen, de was doen, het verzorgen van de administratie, klussen en reparaties in en om het huis, het verzorgen van de kinderen en andere activiteiten met kinderen, zoals spelen, voorlezen of helpen met huiswerk.

\subsubsection{Onafhankelijke variabelen}

In de analyse zijn variabelen opgenomen op het niveau van het huishouden van de vrouw, haar functiegroep en haar arbeidsorganisatie. Op huishoudensniveau gaat het om de relatieve verdiencapaciteit van de vrouw, genderopvattingen, het aantal thuiswonende kinderen en de leeftijd van deze kinderen. Daarnaast voegen we variabelen toe over strategieën voor huishoudbeheersing.

De relatieve verdiencapaciteit wordt gemeten door het relatieve uurloon van de vrouw en is berekend door het netto uurloon van de vrouw te delen door het netto uurloon van haar man. Het netto uurloon is berekend op basis van het netto maandinkomen en het aantal gewerkte uren per week, inclusief overwerk en de eventuele financiële vergoeding daarvoor. $^{2}$ 
Genderopvattingen worden gemeten aan de hand van een Likert-schaal bestaande uit vier items. Voorbeelden daarvan zijn: 'Het is onnatuurlijk als vrouwen in een bedrijf leiding uitoefenen over mannen' en 'Een vrouw is geschikter om kleine kinderen op te voeden dan een man'. Antwoordmogelijkheden lopen van 1 (helemaal mee eens) tot 5 (helemaal niet mee eens). Een lage score staat voor traditionele, seksestereotiepe genderopvattingen, een hoge score staat voor moderne, egalitaire genderopvattingen. De schalen zijn voor vrouwen en mannen apart gemaakt (Cronbach's $\alpha$ is 0,66 voor beide schalen).

De eisen vanuit het gezin die aan partners worden gesteld, zijn gemeten door het aantal thuiswonende kinderen en de leeftijd van deze kinderen. Er zijn drie variabelen opgenomen: het aantal kinderen in het huishouden jonger dan vier jaar, het aantal kinderen tussen vier en twaalf jaar en het aantal kinderen van 13 jaar of ouder.

We onderscheiden in dit onderzoek twee aspecten van huishoudbeheersing: huishoudregels en kwaliteitsstandaarden. Wat betreft huishoudregels werd respondenten gevraagd naar de spelregels die er binnen het huishouden bestaan over de dagelijkse routines van beide partners en de claims op hun tijd. Er zijn vier items opgenomen die meten of partners vaste afspraken thuis hebben. Voorbeelden zijn 'afspraken over niet werken in het weekend' en 'afspraken over op tijd voor het avondeten zijn'. De antwoordcategorieën waren 1 ja, 2 niet echt en 3 nee. Daarnaast zijn er vier items opgenomen die meten in hoeverre respondenten huiselijke activiteiten op vaste tijdstippen doen. Voorbeelden zijn 'boodschappen doen' en 'tijd doorbrengen met het gezin'. Antwoordmogelijkheden varieerden van 1 (nooit) tot 5 (altijd). Samen vormen de acht items een betrouwbare schaal (Cronbach's $\alpha$ is 0,69 ). Omdat de items niet gelijksoortig zijn en verschillende antwoordcategorieën kennen, werden ze eerst gestandaardiseerd en daarna gemiddeld. Een hoge score wijst op strikte huishoudregels.

Respondenten konden op een schaal van 1 tot 10 aangeven hoe hoog hun kwaliteitsstandaarden zijn voor twee huishoudelijke taken: schoonmaken en opruimen. Een 10 betekent dat de taak perfect uitgevoerd moet worden. De scores voor de twee taken werden gemiddeld.

Op het functiegroepniveau worden de eisen die het werk aan de vrouw stelt en haar strategieën voor werkbeheersing in de analyse opgenomen. De eisen vanuit het werk worden gemeten aan de hand van zeven items (Cronbach's $\alpha=0,69$ ). De items meten in hoeverre de functiegroep te maken heeft met targets en deadlines, in hoeverre er een prestatiecultuur heerst en in hoeverre de werknemers snel moeten werken of veel werk moeten verzetten. Vier items werden beantwoord door de direct leidinggevende, die per functiegroep aangaf in hoeverre dat voor die groep geldt. Drie items werden beantwoord door de werkneemster zelf. 
Voor de items die de werkneemsters zelf hebben beantwoord nemen we het gemiddelde van de functiegroep. Alle items zijn gemeten op een vijfpuntsschaal. Een hoge score duidt op veeleisend werk.

De strategieën van de vrouw voor werkbeheersing zijn gemeten door één schaal van 16 items over professionele autonomie en flexibele werkarrangementen (Cronbach's $\alpha=0,87$ ) (zie Van Echtelt, 2007). Negen items werden beantwoord door de direct leidinggevende, die per functiegroep aangaf in hoeverre dat voor die groep geldt. Zeven items werden beantwoord door de werkneemster zelf. Voor deze laatste nemen we het gemiddelde van de functiegroep. Voorbeelden zijn 'Werknemers werken geregeld thuis' en 'Kunt u zelf beslissen hoe u het werk uitvoert?'. Alle antwoorden zijn gemeten op een vijfpuntsschaal. Een hoge score betekent een hoge mate van autonomie en flexibiliteit.

\subsubsection{Controlevariabelen}

Het uitbesteden van huishoudelijk werk kan een manier zijn voor huishoudens om met de tegenstrijdige eisen van werk en gezin om te gaan. Dit is een strategie die vooral wordt ingezet door stellen met hoge inkomens en door werknemers met een hoge mate van professionele autonomie en flexibiliteit in hun werk (De Ruijter, 2005). Ter controle nemen we daarom op werknemersniveau drie variabelen op in de analyses: (a) het aantal uren huishoudelijke hulp dat het huishouden per maand inhuurt, (b) het aantal uren formele kinderopvang dat het huishouden per maand afneemt en (c) een dummy-variabele die aangeeft of het huishouden het afgelopen jaar klussen in en om het huis heeft uitbesteed.

Verder hebben vrouwen met een leidinggevende functie in het algemeen vaker een baan die veeleisend is dan andere vrouwen. Tegelijkertijd beschikken leidinggevende vrouwen over een grotere mate van autonomie en flexibiliteit (McCrate, 2005). Om daarvoor te controleren nemen we een dummy op die aangeeft of een werkneemster een leidinggevende functie heeft $(0=$ nee, $1=j a)$.

Vrouwen uit jongere geboortecohorten verdelen de taken met hun partner vaker gelijk dan vrouwen uit oudere cohorten. Daarom nemen we op het werknemersniveau ook de leeftijd van de werkneemster (in jaren) op als controlevariabele.

Veelal wordt aangenomen dat werk in de profitsector veeleisender is dan werk in de non-profitsector. Werknemers zouden er vaker te maken hebben met een hoge werkdruk en de werksfeer zou competitiever zijn. Tegelijkertijd wordt verondersteld dat het maken van lange werkweken voor werknemers in de profitsector ook meer oplevert in termen van promotie en financiële vergoeding dan voor werknemers in de non-profitsector. Op organisatieniveau nemen we daarom een dummy op voor de sector van de organisatie $(0=$ non profit, $1=$ profit $)$. 


\subsubsection{Interactietermen}

We veronderstellen dat veeleisend werk een verschillend effect heeft op de taakverdeling voor werkneemsters met verschillende 'governance'regimes. Om te toetsen in hoeverre dit zo is, nemen we interactietermen op. Dit zijn drie producttermen tussen werkeisen enerzijds en (1) huishoudregels, (2) kwaliteitsstandaarden, en (3) autonomie en flexibiliteit anderzijds. Alle interactievariabelen zijn vooraf gecentreerd rond het gemiddelde.

\subsection{Analysetechniek}

Het effect van veeleisend werk van vrouwen op de taakverdeling tussen partners wordt onderzocht met multilevel-modellen. Daarmee kunnen we corrigeren voor de geclusterde waarnemingen (Bryk \& Raudenbusch, 1992). ${ }^{3}$ In onze steekproef zijn 242 huishoudens van vrouwelijke werknemers geclusterd binnen 68 functiegroepen waarin deze vrouwen werken, die weer geclusterd zijn binnen 26 arbeidsorganisaties. Voor de analyse is gebruik gemaakt van het pakket MLWin (Rasbash e.a., 2005). Parameters zijn geschat via een maximum likelihood-procedure.

We testen een random intercept model met drie niveaus, waarbij de huishoudens van de vrouwelijke werknemers het eerste niveau vormen, de functiegroepen van de vrouwelijke werknemers het tweede en hun arbeidsorganisaties het derde. We voegen de verklarende variabelen toe in vijf stappen. Het intercept is random, alle andere variabelen worden toegevoegd als fixed. We starten met het lege model, dat alleen bestaat uit een intercept en de residuen op huishoud-, functie- en organisatieniveau (model 1). Dit model laat zien hoeveel variatie toegeschreven kan worden aan elk niveau. In de modellen 2 en 3 worden de variabelen voor werknemers en hun partners toegevoegd. Model 2 test de basishypotheses over relatieve lonen, genderopvattingen en de aanwezigheid en leeftijd van kinderen in het huishouden. Model 3 toetst de effecten van strategieën voor huishoudbeheersing. In model 4 komen de effecten van de werkcontext van vrouwelijke werknemers aan bod. Op functiegroepniveau worden de eisen van het werk van de vrouw en haar strategieën voor werkbeheersing toegevoegd. Op organisatieniveau wordt gecontroleerd voor de sector van de organisatie. Model 5, ten slotte, toetst de interacties tussen de werkeisen van de vrouw en strategieën voor huishoud- en werkbeheersing.

\subsection{Beschrijvende analyses}

Tabel 1 laat de gemiddelden en standaarddeviaties zien voor de vrouwelijke werknemers en hun partners. Het valt op dat de vrouwen en hun 
partners in onze steekproef wat langere werkweken maken en meer uren per week zorgen dan gemiddeld in Nederland. De vrouwen in de steekproef werken gemiddeld 31 uur per week, hun partners 41 uur, terwij1 de gemiddelde werkweek van werkende vrouwen en mannen in Nederland in 2005 respectievelijk 24,9 en 37,2 uur bedraagt (SCP, 2006). Verder besteden de vrouwen in de steekproef gemiddeld bijna 34 uur aan de zorg voor huishouden en kinderen, en hun partners ruim 22 uur, terwijl

Tabel 1 Beschrijvende statistiek van de gebruikte variabelen in de analyses $(n=242$ huishoudens van vrouwelijke werknemers uit 68 functiegroepen en 26 organisaties)

\begin{tabular}{|c|c|c|c|c|c|}
\hline & Gem. & SD & Min. & Max. & $\begin{array}{l}\text { Cron- } \\
\text { bach's } \alpha\end{array}$ \\
\hline \multicolumn{6}{|l|}{ Huishoudniveau $(n=242)$} \\
\hline Uren betaalde arbeid vrouw (per week) & 31,07 & 9,10 & 5,82 & 55,00 & \\
\hline Uren betaalde arbeid partner (per week) & 41,18 & 8,16 & 16,00 & 60,00 & \\
\hline Uren onbetaalde arbeid vrouw (per week) & 33,85 & 16,50 & 5,00 & 72,60 & \\
\hline Uren onbetaalde arbeid partner (per week) & 22,51 & 13,30 & 2,00 & 66,00 & \\
\hline Aandeel vrouw betaalde arbeid (in procenten) & 42,64 & 9,55 & 8,80 & 72,58 & \\
\hline Aandeel vrouw onbetaalde arbeid (in procenten) & 60,14 & 12,90 & 27,09 & 91,11 & \\
\hline Uurloon vrouw (in Euro's) & 14,73 & 1,79 & 11,37 & 19,23 & \\
\hline Uurloon partner (in Euro's) & 16,09 & 3,20 & 10,28 & 22,14 & \\
\hline Relatief uurloon vrouw t.o.v. partner & 0,94 & 0,15 & 0,55 & $\mathrm{I}, 47$ & \\
\hline Moderne genderopvattingen vrouw & 4,12 & 0,63 & 2,50 & 5,00 & 0,66 \\
\hline Moderne genderopvattingen partner & 3,91 & 0,68 & $\mathrm{I}, 75$ & 5,00 & 0,66 \\
\hline Leeftijd vrouw & 38,70 & 8,05 & 23,00 & 59,00 & \\
\hline Leeftijd partner & 41,10 & 8,37 & 23,00 & 62,00 & \\
\hline Aantal kinderen $0 \mathrm{t} / \mathrm{m} 3$ jaar & 0,25 & 0,52 & 0 & 2 & \\
\hline Aantal kinderen $4 \mathrm{t} / \mathrm{m} 12$ jaar & 0,54 & 0,83 & 0 & 3 & \\
\hline Aantal kinderen 13 jaar of ouder & 0,33 & 0,74 & 0 & 6 & \\
\hline Vrouw heeft leidinggevende functie $(0=$ nee, $I=j a)$ & 0,33 & 0,47 & 0 & 1 & \\
\hline $\begin{array}{l}\text { Uitbesteding huishoudelijk werk (in uren per } \\
\text { maand) }\end{array}$ & 4,74 & 7,55 & 0 & 29,8 & \\
\hline Gebruik formele kinderopvang (in uren per maand) & 20,97 & 40,70 & 0 & 192,0 & \\
\hline $\begin{array}{l}\text { Uitbesteding klussen in en om het huis } \\
\qquad(0=\text { nee, I=ja })\end{array}$ & 0,60 & 0,49 & 0 & 1 & \\
\hline Stringente huishoudregels & 0,00 & 0,56 & $-|, 3|$ & 1,69 & 0,69 \\
\hline Hoge kwaliteitsstandaarden huishouden & 6,84 & 0,93 & 3,50 & 9,25 & \\
\hline \multicolumn{6}{|l|}{ Functiegroepniveau $(n=68)$} \\
\hline Veeleisend werk vrouw & 3,21 & 0,53 & 2,00 & 4,29 & 0,69 \\
\hline $\begin{array}{l}\text { Hoge mate van autonomie en flexibiliteit in het } \\
\text { werk vrouw }\end{array}$ & 3,28 & 0,58 & 2,19 & 4,56 & 0,87 \\
\hline \multicolumn{6}{|l|}{ Organisatieniveau $(n=26)$} \\
\hline $\begin{array}{l}\text { Sector }(0=\text { publieke/non-profit sector, } \\
\text { I=private/profit sector })\end{array}$ & 0,31 & 0,47 & 0 & 1 & \\
\hline
\end{tabular}

Bron:Time Competition Survey, 2003 
dat in Nederland gemiddeld 32,8 uur (vrouwen) en 18,1 uur (mannen) is (SCP, 2006). Binnen de huishoudens in onze steekproef nemen vrouwen 60 procent van de totale zorgtijd in het huishouden voor hun rekening en bijna 43 procent van de totale werktijd (ten opzichte van hun part-

ner, exclusief de uren die het huishouden uitbesteedt aan derden). De taakverdeling binnen het huishouden is daarmee iets minder scheef dan gemiddeld in Nederland, waar vrouwen 64,3 procent van de zorgtaken binnen het huishouden op zich nemen (SCP, 2009).

\section{Resultaten}

\section{I De verdeling van betaalde arbeid}

Tabel 2 geeft de resultaten van de multilevel-analyses over de verdeling van betaald werk binnen huishoudens. Uit het lege model (model 1) blijkt dat ongeveer 73 procent van de variantie in de verdeling van betaald werk is toe te schrijven aan variatie tussen werknemers en 21 procent aan variatie tussen functiegroepen. Het gedeelte van de variatie dat te wijten is aan verschillen tussen organisaties (5,5 procent), is niet significant.

Model 2, waarin alleen de individuele en gezinskenmerken zijn opgenomen, laat zien dat het relatieve uurloon van de vrouw (H1a), de aanwezigheid van schoolgaande kinderen in het huishouden (H2a) en de genderopvattingen van beide partners (H3a) het verwachte effect hebben op de verdeling van betaald werk tussen partners. Een hoger relatief uurloon van de vrouw en moderne genderopvattingen vergroten het aandeel van de vrouw in betaald werk. De aanwezigheid van schoolgaande kinderen verkleint haar aandeel. De aanwezigheid van jonge kinderen $(0$ tot en met 3 jaar) heeft, anders dan we verwacht hadden, geen effect op de verdeling van betaald werk in het huishouden. Nadere bestudering van de cijfers laat zien dat dit komt doordat beide partners in gelijke mate minder uren werken als er jonge kinderen in het huishouden zijn (niet in de tabel opgenomen). We vinden daarmee geen ondersteuning voor hypothese $2 \mathrm{c}$.

In model 3 worden de strategieën voor huishoudbeheersing in de analyse opgenomen. Zoals hypothese 5 a voorspelde, lijkt er een licht positief effect te zijn van huishoudregels op het aandeel van de vrouw in betaald werk $(1,883, p<0,10)$. Het model verbetert echter niet significant $(\Delta$ deviance: $4,876, \Delta d f: 5, p>0,10)$. Kwaliteitsstandaarden hebben geen effect op de verdeling van betaald werk. Hypothese $8 \mathrm{a}$ wordt niet ondersteund.

Model 4 toetst de invloed van de werkcontext van vrouwen op de verdeling van betaald werk binnen hun huishouden. Het model verbetert significant ( $\Delta$ deviance: $23,214, \Delta d f: 3, p<0,001$ ). Conform onze ver- 


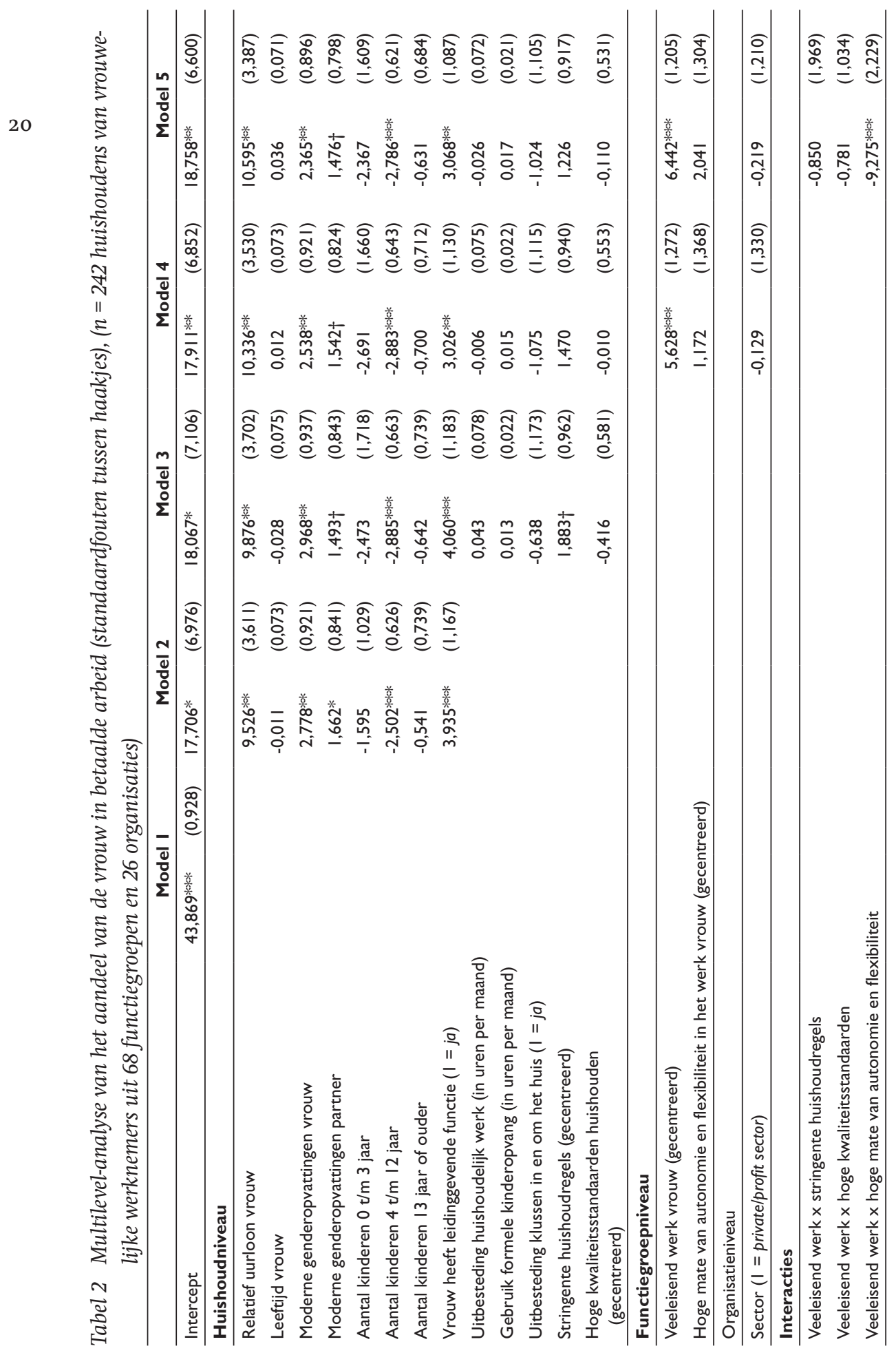




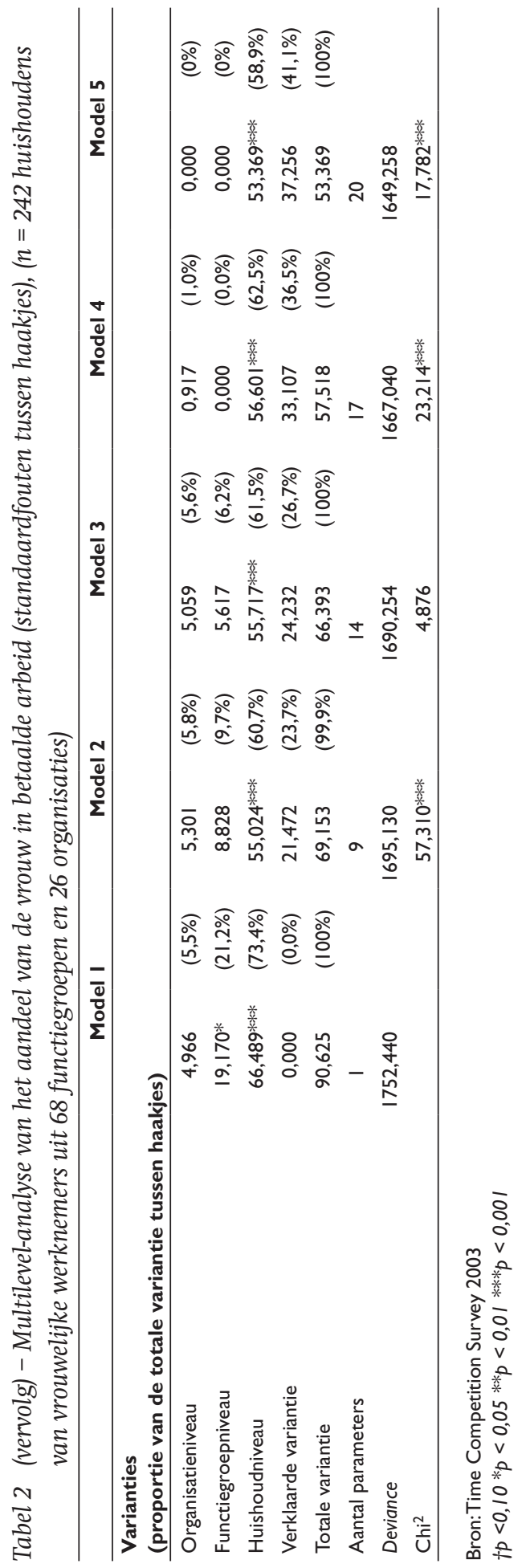


wachtingen hebben hoge werkeisen tot gevolg dat vrouwen een groter deel van het betaalde werk in het huishouden op zich nemen (H4a). De taakverdeling tussen de partners wordt daardoor gelijker. Een dergelijke verandering in het relatieve aandeel van de vrouw in betaald werk kan verschillende oorzaken hebben. Iemands aandeel wordt groter wanneer zij zelf meer uren gaat werken terwijl en haar partner evenveel blijft werken, maar ook wanneer zij evenveel blijft werken terwijl haar partner zijn uren mindert. Nadere bestudering van de gewerkte uren van beide partners laat zien dat het grotere aandeel hier ontstaat doordat vrouwen zelf meer uren werken naarmate de eisen die het werk aan hen stelt hoger zijn, terwijl de arbeidsuren van hun partner niet veranderen. In tegenstelling tot onze verwachtingen hebben strategieën voor werkbeheersing geen effect op de verdeling van betaald werk tussen partners. Hypothese 10a wordt niet bevestigd.

De interacties in model 5 laten zien dat alleen strategieën voor werkbeheersing het effect van werkeisen op de verdeling van betaald werk tussen partners beïnvloeden. Onze verwachting was dat een grote mate van autonomie en flexibiliteit het tijdslurpende effect van werkeisen op het aandeel van de vrouw in betaald werk binnen het huishouden zou intensiveren (H11a). De resultaten laten echter het tegengestelde zien: een grote mate van autonomie en flexibiliteit op het werk blijkt juist het positieve effect van werkeisen te verminderen. Figuur 1 geeft dit effect weer. Voor vrouwen die werken in functies met een hoge mate van autonomie en flexibiliteit, hebben de eisen die het werk aan hen stelt nauwelijks invloed op de verdeling van betaald werk thuis. Zowel bij hoge als lage werkeisen nemen deze vrouwen een relatief groot deel van de betaalde arbeid in het huishouden op zich. Merk op dat bij een hele hoge mate van autonomie en flexibiliteit het effect van veeleisend werk op het aandeel van de vrouw in betaalde arbeid zelfs negatief wordt. Dit komt doordat vrouwen dan minder uren gaan werken. Voor vrouwen met een lage mate van autonomie en flexibiliteit op het werk daarentegen is de verdeling van het betaalde werk wel afhankelijk van de eisen die het werk aan hen stelt. Naarmate de eisen die het werk aan hen stelt hoger zijn, nemen zij thuis een groter deel van het betaalde werk voor hun rekening.

We vinden geen ondersteuning voor de hypothesen dat huishoudregels het effect van veeleisend werk op de verdeling van betaalde arbeid intensiveren (H6a) of afzwakken (H7a). Ook kwaliteitseisen blijken geen invloed te hebben op de gevolgen van veeleisend werk voor de verdeling van betaalde arbeid (H9a). 
Figuur 1 Het effect van veeleisend werk op het aandeel van de vrouw in betaalde arbeid, voor vrouwelijke werknemers met weinig, gemiddeld en veel autonomie en flexibiliteit op het werk

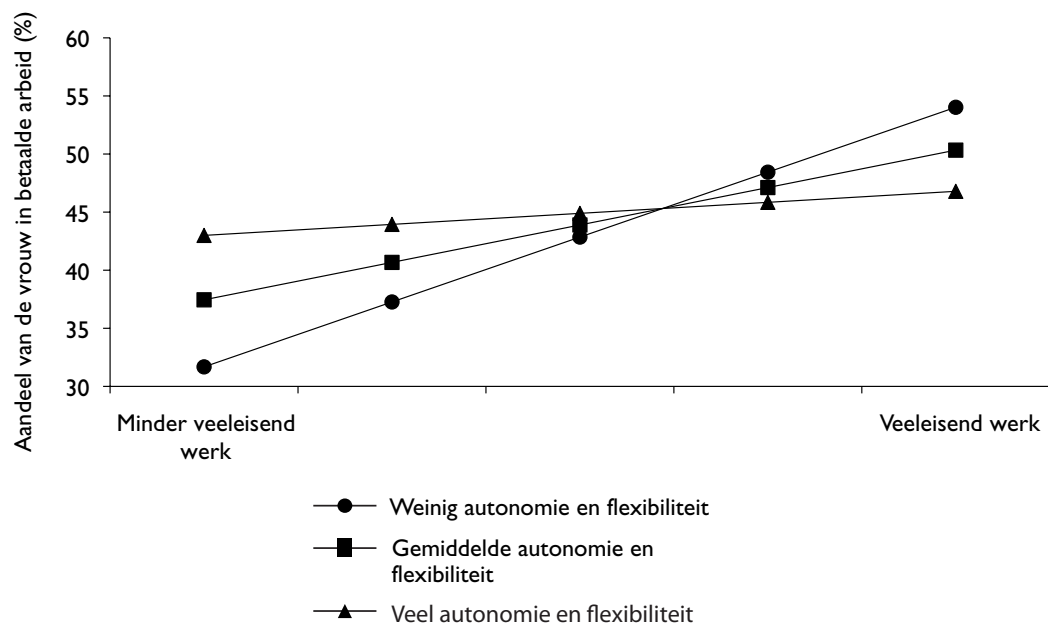

Bron:Time Competition Survey 2003

Noot bij de tabel: De 'gemiddelde autonomie en flexibiliteit' is berekend op basis van de gemiddelde waarde op deze variabele. 'Weinig autonomie en flexibiliteit' is één standaarddeviatie onder het gemiddelde en 'veel autonomie en flexibiliteit' één standaarddeviatie er boven. De figuur is gebaseerd op de geschatte parameters uit model 5 in tabel 2 , bij gemiddelde waarden op alle andere variabelen.

\subsection{De verdeling van onbetaalde arbeid}

In tabel 3 worden de resultaten van de analyses over de verdeling van onbetaalde arbeid tussen partners gepresenteerd. Model 1 laat zien dat de variantie in de verdeling van onbetaalde arbeid vooral te wijten is aan variatie tussen werknemers (85,1 procent) en veel minder aan de variatie tussen functiegroepen $(12,6$ procent, $p>0,10)$ en organisaties $(2,3$ procent, $p>0,10)$.

Uit model 2 blijkt dat vooral de leeftijd van de vrouw casus quo haar geboortecohort een goede voorspeller is van de verdeling van onbetaalde arbeid. Naarmate vrouwen ouder zijn, nemen ze een groter deel van de onbetaalde arbeid in het huishouden op zich en is de taakverdeling ongelijker. In tegenstelling tot onze verwachting heeft het relatieve uurloon van de vrouw geen effect op de verdeling van onbetaalde arbeid, waarmee hypothese $1 \mathrm{~b}$ niet ondersteund wordt. Conform de verwachtingen maakt de aanwezigheid van schoolgaande kinderen de verdeling van onbetaalde arbeid schever (H2b). Egalitaire genderopvattingen leiden tot een gelijkere verdeling (H3b). De aanwezigheid van jonge kinderen (0 tot en met 3 jaar) en adolescenten (13 jaar of ouder) daarentegen heeft geen effect op de verdeling van onbetaald werk in het huishouden, omdat 


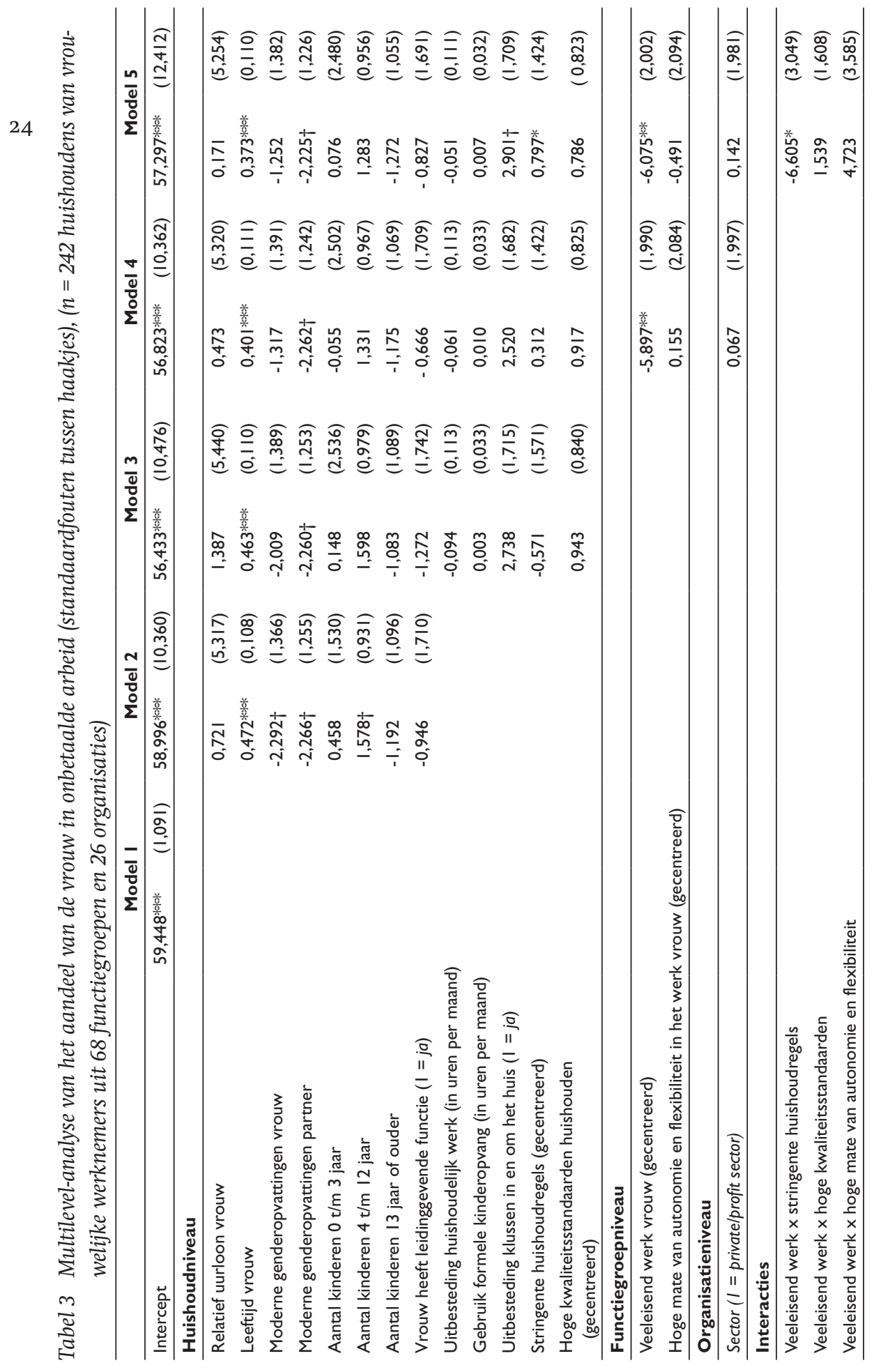




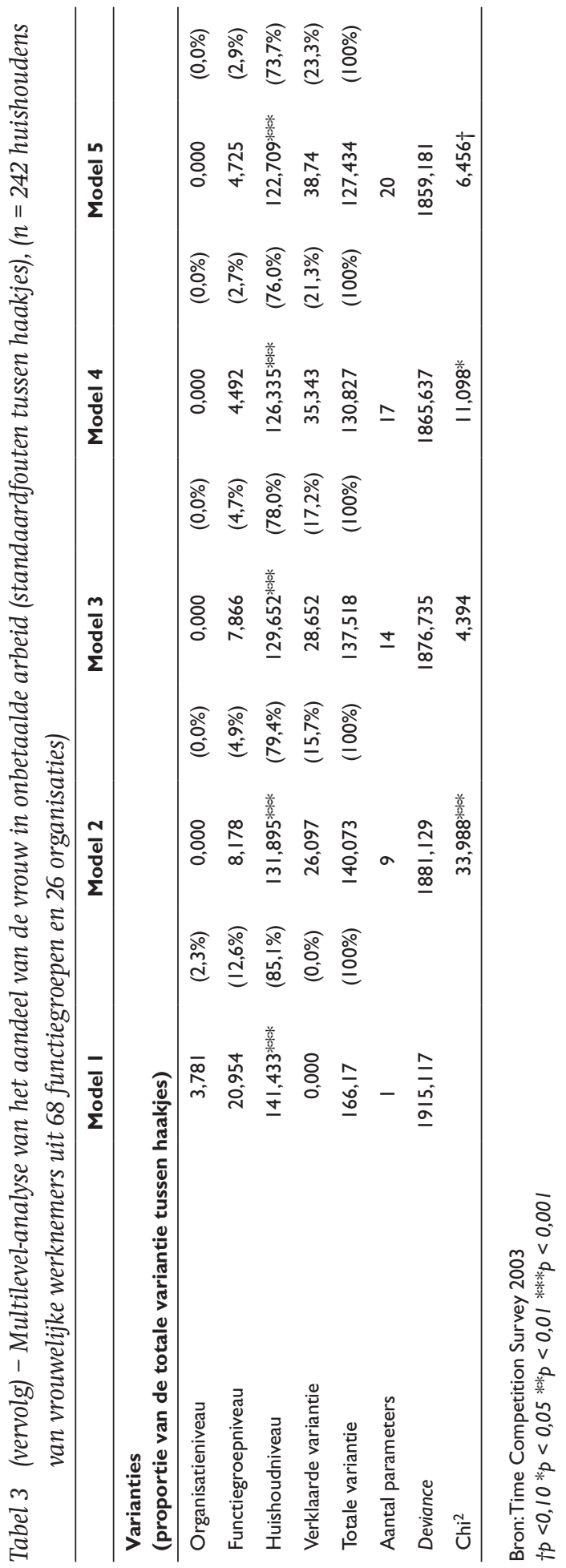


beide partners ongeveer in gelijke mate meer uren blijken te besteden aan huishoudelijk werk en zorgtaken als er jonge kinderen of adolescenten in het huishouden zijn. Hypothese $2 \mathrm{c}$ wordt niet ondersteund.

In tegenstelling tot onze verwachtingen blijkt geen van de strategieen voor huishoudbeheersing in model 3 effect te hebben op de verdeling van onbetaalde arbeid tussen partners. Hypothese $5 \mathrm{~b}$ over het effect van huishoudregels en hypothese $8 \mathrm{~b}$ over het effect van kwaliteitsstandaarden worden niet bevestigd. Analyses van de netto uren die beide partners aan huishoudelijk werk en zorgtaken besteden (niet in de tabel opgenomen), laten zien dat huishoudregels noch kwaliteitsstandaarden daarop van invloed zijn, waardoor ook de taakverdeling onveranderd blijft.

De toevoeging van de werkcontext van de vrouwen in model 4 laat zien dat deze, zoals verwacht, van invloed is op de verdeling van onbetaalde arbeid binnen het huishouden. Naarmate het werk hogere eisen aan hen stelt, is het aandeel van vrouwen aan onbetaalde arbeid kleiner en wordt de taakverdeling thuis daardoor gelijker (H4b). Deze gelijkere verdeling komt niet doordat vrouwen zelf minder in het huishouden doen als hun baan veeleisend is, maar doordat hun partners dan meer gaan doen.

De strategieën van vrouwen voor werkbeheersing hebben geen effect op de verdeling van huishoudelijk werk tussen hen en hun partner (H10b). Wel zorgen autonomie en flexibiliteit ervoor dat het huishouden netto minder uren aan huishoudelijk werk en kinderzorg gaat besteden: zeven uur per week minder bij een stijging van een punt op de schaal voor werkbeheersing (niet in de tabel opgenomen). Het negatieve effect van autonomie en flexibiliteit op de netto uren die besteed worden aan onbetaalde arbeid is voor beide partners even groot, waardoor de verdeling van taken onveranderd blijft.

Model 5 toetst de interactie-effecten tussen de werkeisen van vrouwen en hun strategieen voor huishoud- en werkbeheersing. Hoewel de verbetering van het model gering is ( $\Delta$ deviance: $1859,181, \Delta d f: 3$, $p<0,10)$, laten de analyses zien dat het effect van veeleisend werk op de verdeling van onbetaalde arbeid significant afhangt van de strategieën voor huishoudbeheersing binnen het huishouden. In figuur 2 is goed te zien dat het negatieve effect van de werkeisen van vrouwen op hun aandeel aan onbetaalde arbeid sterker is naarmate er thuis stringentere huishoudregels gelden. We vinden daarmee ondersteuning voor hypothese $6 \mathrm{~b}$ en niet voor $7 \mathrm{~b}$. Strikte huishoudregels zorgen ervoor dat mannelijke partners extra tijd besteden aan huishoudelijk werk wanneer het werk van hun vrouw veeleisend is (niet in de tabel opgenomen). Het effect van veeleisend werk van vrouwen op de verdeling van onbetaalde arbeid binnen het huishouden, is niet afhankelijk van de kwaliteitseisen binnen het huishouden of van de strategieën van vrouwen voor werkbeheersing, waarmee de hypothesen $9 \mathrm{~b}$ en $11 \mathrm{~b}$ niet worden ondersteund. 
Figuur 2 Het effect van veeleisend werk op het aandeel van de vrouw in onbetaalde arbeid, voor vrouwelijke werknemers met flexibele, gemiddelde en stringente huishoudregels

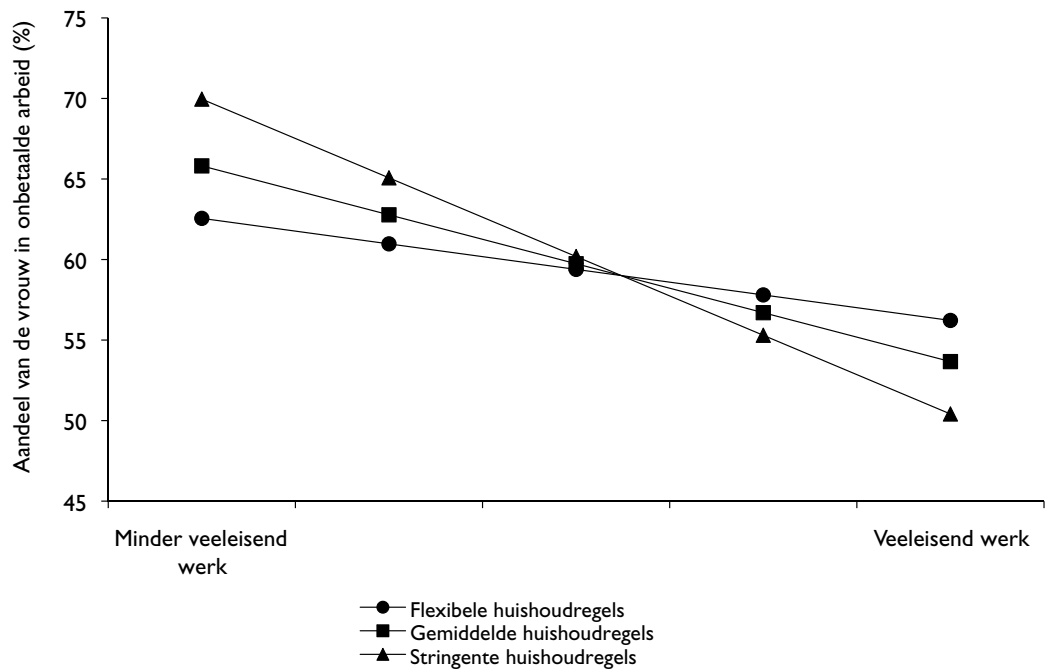

Bron:Time Competition Survey 2003

Noot bij de tabel: 'Gemiddelde huishoudregels' zijn berekend op basis van de gemiddelde waarde op deze variabele. 'Flexibele huishoudregels' zijn één standaarddeviatie onder het gemiddelde en 'Stringente huishoudregels' één standaarddeviatie er boven. De figuur is gebaseerd op de geschatte parameters uit model 5 in tabel 3, bij gemiddelde waarden op alle andere variabelen.

\section{Conclusie en discussie}

Ondanks de omvangrijke literatuur over de arbeidsverdeling tussen partners binnen huishoudens is tot dusver weinig bekend over het effect daarop van eisen en verwachtingen vanuit het werk van elk van de partners. Eerder onderzoek heeft wel duidelijk laten zien dat eisen vanuit het gezin, zoals de aanwezigheid van (jonge) kinderen en de daaruit voortvloeiende vraag naar tijd en energie, vergaande consequenties hebben voor de tijdsbesteding van en arbeidsverdeling tussen partners. Tegen deze achtergrond hebben wij betoogd dat 'gulzige' organisaties eveneens hoge eisen stellen aan de tijd en energie die werknemers 'in hun baan' stoppen en dat deze eisen net zo goed van invloed zijn op de tijdsbesteding van en arbeidsverdeling tussen partners. In onze aanpak zijn we ervan uit gegaan dat werknemers die eisen vanuit het werk niet zonder meer accommoderen. Zij reageren op die eisen door strategieën, en formele en informele besluitvormingsprocedures en -criteria te gebruiken om te bepalen waar zij hun dagelijkse tijd en energie aan besteden. 
Op basis van gegevens van 242 vrouwelijke werknemers, hun werkgevers en hun partners uit het Dutch Time Competition Survey 2003, hebben we multilevel-modellen geschat ter verklaring van de verdeling van betaalde en onbetaalde arbeid tussen partners. Daarbij is met name aandacht besteed aan de rol van de eisen die het werk van de vrouw stelt en de mate waarin bepaalde 'governance'-regimes eraan bijdragen het probleem van de concurrerende claims tussen werk en gezin op te lossen. De uitkomsten van onze analyses laten zien dat behalve de relatieve verdiencapaciteit, genderopvattingen en de eisen die het gezin aan partners stelt, ook de eisen vanuit het werk van de vrouw een groot effect hebben op de arbeidsverdeling tussen partners. Hoe meer een baan van een vrouw vraagt, hoe groter haar aandeel in het betaalde werk dat vanuit een huishouden wordt verricht en hoe kleiner haar aandeel in het onbetaalde werk. Het grotere aandeel van de vrouw in het aantal betaalde uren valt geheel toe te schrijven aan een toename van haar eigen betaalde uren. De tegelijkertijd optredende afname van haar aandeel in het onbetaalde werk wordt veroorzaakt doordat haar partner daar meer uren aan besteedt. Sterke claims vanuit het huishouden dragen bij aan een traditionele rolverdeling tussen partners. Op vergelijkbare wijze dragen hoge eisen vanuit het werk en de organisatie bij aan een meer gelijkwaardige verdeling van betaalde en onbetaalde activiteiten binnen huishoudens.

Het effect op de taakverdeling van de eisen die het werk stelt, verschilt echter afhankelijk van de strategie die huishoudens hanteren om met concurrerende claims op hun tijd om te gaan en afhankelijk van de flexibiliteit en de autonomie die de vrouw in haar baan geniet. Onze theoretische verwachting dat een strategie op huishoudenniveau, uitmondend in 'spelregels' en afspraken een matigende invloed op het effect van de claims vanuit het werk zou leiden, vindt gedeeltelijk ondersteuning. Dergelijke spelregels en afspraken versterken het effect van de eisen vanuit het werk op de verdeling van huishoudelijk werk, maar niet op de verdeling van het betaalde werk binnen het huishouden. Dergelijke regels en afspraken helpen de vrouw kennelijk grenzen te stellen aan haar huishoudelijke taken om zodoende beter de claims vanuit haar werk te kunnen honoreren. Meer regels en afspraken op huishoudenniveau vormen dus een nuttig instrumentarium om vrouwen aan de tijdklem te helpen ontsnappen als de druk vanuit hun werk toeneemt.

Naarmate de vrouw in haar werk over meer flexibiliteit en autonomie beschikt, hebben hogere eisen vanuit de organisatie minder effect op de verdeling van betaald werk binnen het huishouden. Flexibiliteit en autonomie hebben dus een dempend effect op de gevolgen van de claims vanuit de organisatie voor de taakverdeling tussen partners. Dit leidt tot de ietwat tegenstrijdige conclusie dat flexibiliteit en autonomie 
op het werk vrouwen enerzijds een wat meer ontspannen bestaan lijken te bieden, maar flexibiliteit en autonomie anderzijds bijdragen aan het in stand houden van een meer traditionele rolverdeling binnen huishoudens. Evenals eerder onderzoek suggereren de uitkomsten van ons onderzoek dat mannen hun tijdbestedingspatronen niet aanpassen en meer huishoudelijke taken op zich nemen, zolang hun vrouw daarvoor beschikbaar is (Noonan, Estes \& Glass, 2007)

Bij de interpretatie van de uitkomsten dient wel te worden bedacht dat het gebruik van cross-sectionele data in ons onderzoek niet de mogelijkheid biedt rekening te houden met eventuele omgekeerde causaliteit. We weten bijvoorbeeld immers niet of - in de tijd bezien - huishoudens zich hebben aangepast aan toenemende claims vanuit het werk of dat de wijze waarop de verdeling van rollen en taken binnen het huishouden vrouwen de mogelijkheid heeft geboden een baan aan te nemen die hogere eisen stelt. Zoals verschillende studies hebben laten zien, kunnen 'onderhandelingen' over de verdeling van taken binnen huishoudens als een dynamisch proces worden beschouwd (Kluwer, 1998; Kluwer, Heesink \& Van der Vliert, 1997), waarin partners bij voortduring de mogelijkheden aftasten om de concurrerende claims vanuit gezin en werk met elkaar te verzoenen (Perlow, 1998). Toekomstig onderzoek zou meer licht moeten werpen op vraagstukken met betrekking tot (omgekeerde) causaliteit en simultaniteit van de binnen huishoudens gemaakte keuzes.

Onze analyses hebben zich beperkt tot data voor Nederlandse huishoudens. Internationaal-vergelijkend onderzoek zal moeten uitwijzen in hoeverre vergelijkbare effecten van 'governance'-regimes worden gevonden in landen waar niet zoals in Nederland een sterke deeltijdcultuur heerst en waar burgers een gelijke verdeling van betaald en onbetaald werk tussen partners minder hoog in het vaandel hebben staan (Plantenga, Schippers \& Siegers, 1999).

Omdat de data hierin niet voorzagen, hebben we in dit onderzoek geen rekening kunnen houden met het effect van de baan en de vanuit die baan gestelde eisen aan de tijdbesteding van de man. Enerzijds kan worden verondersteld dat de flexibiliteit en autonomie in zijn baan eveneens van invloed is op de taakverdeling binnen het huishouden. Anderzijds weten we uit eerder onderzoek dat mannen veel minder dan vrouwen geneigd zijn hun betaalde activiteiten aan te passen aan hun huishoudelijke taken. Toekomstig onderzoek zal moeten uitwijzen wiens baan de grootste invloed heeft op de taakverdeling op huishoudenniveau en op de wijze waarop partners hun 'governance'strategieën inzetten om tot een optimale taakverdeling te komen.

Ondanks deze beperkingen toont ons onderzoek dat eisen op het werk en van de werkgever een rol kunnen spelen als het er om gaat vrouwen meer uren te laten werken en een herverdeling van onbe- 
taalde taken op huishoudenniveau op gang te brengen. Deze uitkomst lijkt beleidsmatig van belang in het licht van het feit dat het in oktober 2010 aangetreden kabinet-Rutte de emancipatie van vrouwen wel min of meer voltooid acht en aan verdere stimulering en ondersteuning van dat proces in elk geval vanuit het overheidsbeleid niet bijster veel energie en financiële middelen wenst te spenderen. In combinatie met de noodzaak dat vrouwen in de toekomst meer (uren) zullen moeten gaan werken om de als gevolg van de ontgroening en vergrijzing dreigende tekorten op de arbeidsmarkt het hoofd te kunnen bieden, lijken sociale partners zelf het heft in handen te moeten nemen. Ons onderzoek laat zien dat inspanningen van de zijde van werkgevers daarbij kansrijk kunnen zijn. Sociale partners zullen zich dan nog wel moeten buigen over de wijze waarop in de toekomst met thema's als flexibiliteit en autonomie moet worden omgegaan. Deze 'governance'-instrumenten worden immers veelal aangeprezen als adequate hulpmiddelen om werknemers in staat te stellen hun taken op het werk op optimale wijze uit te voeren, maar blijken - zo leert ons onderzoek - ook een remmende werking te hebben op het doorbreken van de traditionele taakverdeling thuis.

\section{Noten}

1 Babette Pouwels is verbonden aan de capaciteitsgroep Sociologie van de Erasmus Universiteit Rotterdam, Jacques Siegers en Joop Schippers aan het Departement Economie van de Universiteit Utrecht, Rafael Wittek aan de afdeling Sociologie/ICS van de Rijksuniversiteit Groningen en Philip Wotschack aan het Social Science Research Center (WZB) in Berlijn. Correspondentie: Babette Pouwels, Erasmus Universiteit Rotterdam, Faculteit Sociale Wetenschappen, Postbus 1738, 3000 DR Rotterdam, pouwels@fsw.eur.nl. De auteurs bedanken Jan Dirk Vlasblom voor zijn econometrische advies bij het berekenen van de uurlonen.

2 Omdat het uurloon mede is bepaald op basis van het aantal uren betaalde arbeid, levert dat problemen op wanneer we uurlonen in het model willen opnemen om het relatieve aandeel van vrouwen in betaalde arbeid te verklaren. Meetfouten in het aantal uren betaalde arbeid hebben immers tot gevolg dat er meetfouten ontstaan in het uurloon. Deze zijn sterk negatief gecorreleerd, waardoor de geschatte parameter van het uurloon een negatieve bias heeft. In de literatuur staat dit verschijnsel bekend als division bias (Borjas, 1980). Een oplossing is om niet het uurloon zelf, maar het geschatte uurloon als predictor op te nemen. Deze is immers niet gecorreleerd met de meetfout in het aantal uren betaalde arbeid (Hall, 1973). We maken daarbij gebruik van Minceriaanse loonvergelijking (Mincer, 1974). Opleiding is gemeten in aantal effectieve scholingsjaren. De loonvergelijking werd apart geschat voor vrouwen en mannen:

Netto uurloon vrouwelijke werknemers $=$ $\exp \left(4.812+0.006 *\right.$ leeftijd $-0.054 *$ leeftijd ${ }^{2}-0.358$ opleiding $+0.939 *$ opleiding ${ }^{2}+$ $0.285 *$ leeftijd*opleiding $+0.22940 * 0.22940 / 2)$.

Netto uurloon mannelijke partners $=\exp \left(3.414+0.029 *\right.$ leeftijd $-0.074 *$ leeftijd ${ }^{2}$ $0.272 *$ opleiding $+0.775 *$ opleiding ${ }^{2}+0.266^{*}$ leeftijd*opleiding $+0.24203^{*} 0.24203 / 2$ ) .

3 Regressie-analyses met correctie voor de clustering van werknemers binnen fuctiegroepen in organisaties laten vergelijkbare resultaten zien. 


\section{Literatuur}

Acker, J. (1998). The future of gender and organizations: Connections and boundaries. Gender, Work, and Organizations, 5, 195-206.

Becker, G.S. (1981, 1991). A treatise on the family. Cambridge, Mass./London, UK: Harvard University Press.

Benschop, Y. (1996). Covered by equality: Gender in organizations. Dissertatie Katholieke Universiteit Nijmegen.

Bianchi, S.M., Milkie, M.A., Sayer, L.C. \& Robinson, J.P. (2000). Is anyone doing the housework? Trends in the gender division of household labor. Social Forces, 79, 191-228.

Bittman, M., England, P., Sayer, L., Folbre, N. \& Matheson, G. (2003). When does gender trump money? Bargaining and time in household work. American Journal of Sociology, 109, 186-214.

Blood, R.O. \& Wolfe, D.M. (1960). Husbands \& wives. The dynamics of married living. Glencoe, CA: Free Press of Glencoe.

Blossfeld, H.P. \& Drobnič, S. (red.). (2001). Careers of couples in contemporary societies: From male Breadwinner to dual earner families. Oxford, UK: University Press.

Borjas, G.J. (1980). The relationship between wages and weekly hours of work: The role of division bias. The Journal of Human Resources, 15, 409423.

Bovenberg, A.L. (2005). Balancing work and family life during the life course. De Economist, 153, 399-423.

Brines, J. (1994). Economic dependency, gender, and the division of labor at home. American Journal of Sociology, 100, 652-688.

Bryk, A.S. \& Raudenbush, S.W. (1992). Hierarchical linear models. Newbury Park, US: Sage Publications.

Clarkberg, M. \& Moen, P. (2001). Understanding the time-squeeze: Married couples' preferred and actual work-hour strategies. American Behavioral Scientist, 44, 1115-1135.

Coltrane, S. (2000). Research on household labor: modeling and measuring the social embeddedness of routine family work. Journal of Marriage and the Family, 62, 1208-1233.

Coser, L.A. (1974). Greedy institutions: Patterns of undivided commitment. New York: Free Press.

Cunningham, M. (2007). Influences of women's employment on the gendered division of household labor over the life course: Evidence from a 31-year panel study. Journal of Family Issues, 28, 422-444.

Echtelt, P. van (2007). Time-greedy employment relationships. Four studies on the time claims of post-Fordist work. Dissertatie Rijksuniversiteit Groningen.

Jacobs, J.A., \& Gerson, K. (2001). Overworked individuals or overworked families? Explaining trends in work, leisure, and family time. Work and Occupations, 28, 40-63. 
Jonge, J. de, Dollard, M.F., Dormann, C., Le Blanc, P.M. \& Houtman, I.L.D. (2000). The demand-control model: Specific demands, specific control, and well-defined groups. International Journal of Stress Management, 7, 269-287.

Gill, G.K. (1998). The third job: Employed couples' management of household work contradictions. Brookfield, VT: Ashgate.

Glass, J. \& Camarigg, V. (1992). Gender, parenthood and job-family compatibility. American Journal of Sociology, 98, 131-151.

Greenstein, T.N. (1996). Husband's participation in domestic labor: Interactive effects of wives' and husband's gender ideologies. Journal of Marriage and the Family, 58, 585-595.

Greenstein, T.N. (2000). Economic dependence, gender and the division of labor in the home: A replication and extension. Journal of Marriage and the Family, 62, 322-335.

Hall, R.E. (1973), Wages, income, and hours of work in the U.S. labor force, In: G.G. Cain \& H.W. Watts (red.), Income maintenance and labor supply. Econometric studies (pp. 102-162). Chicago: Rand McNally College Publishing Company.

Hochschild, A.R. (1997). The time bind: When work becomes home and home becomes work. New York: Metropolitan Books.

Kluwer, E.S., Heesink, J.A.M. \& Van de Vliert, E. (1997). The marital dynamics of conflict over the division of labor. Journal of Marriage and the Family, 59, 635-653.

Kluwer, E. (1998). Responses to gender inequality in the division of family work: The status quo effect. Social Justice Research, 11, 337-357.

Lewin-Epstein, N., Stier, H. \& Braun, M. (2006). The division of household labor in Germany and Israel. Journal of Marriage and Family, 68, 11471164.

Lippe, T. van der \& Siegers, J.J. (1994). Division of household and paid labour between partners: Effects of relative wage rates and social norms. Kyklos, 47, 109-136.

Lippe, T. van der \& Glebbeek, A. (2003). Time competition survey. Utrecht/ Groningen: ICS, Utrecht University/University of Groningen.

Maume, D.J. \& Bellas, M.L. (2001). The overworked American or the time bind? Assessing competing explanations for time spent in paid labor. American Behavioral Scientist, 44, 1137-1156.

McCrate, E. (2005). Flexible hours, workplace authority, and compensating wage differentials in the US. Feminist Economics, 11, 11-39.

Mincer, J. (1974). Schooling, experience, and earnings. New York: National Bureau of Economic Research.

Noonan, M.C., Estes, S.B. \& Glass, J.L. (2007). Do workplace flexibility policies influence time spent in domestic labor? Journal of Family Issues, 28, 263-288. 
Perlow, L.A. (1998). Boundary control: The social ordering of work and family time in a high-tech corporation. Administrative Science Quarterly, 43, 328-357.

Plantenga, J. \& Remery, C. (2005). Reconciliation of work and private life: A comparative review of thirty European countries. Brussels: The European Commission, Directorate-General for Employment, Social Affairs and Equal Opportunities.

Presser, H.B. (1994). Employment schedules among dual-earner spouses and the division of household labor by gender. American Sociological Review, 59, 348-364.

Rasbash, J., Steele, F., Browne, W.J. \& Prosser, B. (2005). A user's guide to MLwiN. Bristol, UK: University of Bristol, Centre for Multilevel Modelling.

Rutherford, S. (2001). 'Are you going home already?' The long hours culture, women managers and patriarchal closure. Time \& Society, 10, 259276.

Ruijter, E. de (2005). Household outsourcing. Dissertatie Universiteit Utrecht.

Evertsson, M. \& Nermo, M. (2004). Dependence within families and the division of labor: Comparing Sweden and the United States. Journal of Marriage and Family, 66, 1272-1286.

Schippers, J.J. (2001). Arbeidsmarkt- en emancipatiebeleid: De vraag naar diversiteit. Oratie Universiteit Utrecht.

Schor, J.B. (1993). The overworked American: The unexpected decline of leisure. New York: Basic Books.

SCP (2006). Emancipatiemonitor 2006: Veranderingen in leefsituatie en levensloop. Den Haag: Sociaal en Cultureel Planbureau.

SCP (2009). Emancipatiemonitor 2008. Den Haag: Sociaal en Cultureel Planbureau.

Shelton, B.A. \& John, D. (1996). The division of household labor. Annual Review of Sociology, 22, 299-322.

Tausig, M. \& Fenwick, R. (2001). Unbinding time: alternate work schedules and work-life balance. Journal of Family and Economic Issues, 22, 101119.

Wotschack, Philip (2009): Household Governance and Time Allocation: Four Studies on the Combination of Work and Care. Dissertatie Rijksuniversiteit Groningen.

Wotschack, P., Siegers, J., Pouwels, B., \& Wittek, R. (2007). Labour supply: The effects of employer demands and household governance. In $\mathrm{T}$. van der Lippe \& P. Peters (red.), Time competition: disturbed balances and new options in work and care (pp.161-175). Cheltenham: Edward Elgar. 